\title{
Re-examination of Gender Diversity Effects on Managerial Efficiency Recent Evidence from Japan -
}

\author{
Motohiro HAGIWARA \\ School of Commerce, Meiji University, \\ 1-1 Kandasurugadai, Chiyoda-ku, Tokyo, 101-0062 Japan
}

\begin{abstract}
In the midst of globalization, a declining birthrate, and an aging population, it has long been recognized that Japan's labor market needs to better utilize female workforce. Among developed countries, Japan lags in terms of utilizing its female workforce. Various interrelated factorsincluding the custom of lifetime employment, long working hours for full-time employees, lack of measures to support work-childcare balance, discrimination against female employees in the workplace, and a lack of job market awareness among working women-are responsible for this lag in female workforce participation. However, if female workforce participation can enhance corporate earnings and competitiveness (a growing need in the current economic environment), actively promoting the utilization of female workforce may help companies improve their performance.
\end{abstract}

Key words: Stock pricing, Female workforce, Risk management

\section{Introduction}

To ascertain the positive impact on corporate performance by women executives, an analysis of data of major US firms for the years 1993 and 1998 was conducted, [1] which showed that the higher the percentage of women and minorities in executive roles, the greater the return on assets (ROA) and return on investment (ROI). Regarding the hypothesis that gender diversity among corporate boards of directors contributes to corporate performance, [2] found that gender diversity among a board of directors improves the board's ability to monitor and make decisions through nontraditional, innovative approaches and sends important positive signals to the labor, product, and financial markets.

On the negative side, however, [3] concluded that there is no relationship between women directors and corporate performance. [4] showed that although women directors contribute to increased levels of monitoring in corporate board, they have a negative impact on corporate performance. In addition, [4] indicated that excessive monitoring damages corporate values.

On the basis of evidence from Japan, [4] addressed issues not identified in previous research (because of data constraints). Utilizing government statistical data of Japanese companies, these researchers conducted a survey on whether hiring women managers had a positive impact on corporate earnings in the 2000s. This study cited cost savings from the low salary paid to female officers and managers as a reason for higher corporate earnings.

With active discussion taking place in Europe regarding the obligatory hiring of female executives, the obligatory hiring of female executives in Japan-a nation with an extremely low percentage of female executives - is likely to become a major topic. This study investigates the correlation between the percentage of female executives and corporate performance. [5] confirmed that groups with gender and racial diversity can make better decision. Furthermore, [4] concluded that excessive monitoring by corporate boards damages corporate values. However, since the percentage of outside directors is low in Japan, it cannot be surmised that the participation of female directors would lead to excessive monitoring. Therefore, [6] formulated the hypothesis that companies with a high ratio of female directors perform relatively strongly. The results of [6] demonstrate that the percentage of female executives does not have a relationship with ROA; however, it

*corresponding author: motohiro@meiji.ac.jp

Received: February 16, 2015

Accepted: November 2, 2015 


\section{Motohiro HAGIWARA}

does show a positive effect on Tobin's $q$. This is because, although ROA reflects financial performance, Tobin's $q$ includes stock market valuation, which takes into account both short-term profitability and long-term growth and includes an assessment of risk as well as profitability. [6] therefore suggested that women executives contribute to future financial performance rather than to current, short-term financial performance, as reflected in the ROA. [6] does not imply that a fixed ratio of women executives should be mandatory. [7] reported that in the context of Norway's limited human resources, the country's 2003 mandate that $40 \%$ of directors be women led to the rapid appointment of women to boards, a consequent increase in the number of inexperienced directors, and a resulting decline in corporate performance. Clearly, more research should be conducted on the topic of institutionalizing quotas for female executives.

This study performed multivariate analysis using market capitalization, the ratio of interest-bearing liabilities, average annual salary, and fiscal year dummy variables as control variables. It also used excess stock return, ROA, and stock price volatility as dependent variables. The female factors are used to emphasize the relationship between excess stock return and stock price volatility and directly demonstrate the impact on corporate performance and ROA. In addition, subdivision of industry types is focused based on the hypothesis that the relationship between female factors and corporate performance could differ depending on the type of industry. Moreover, while previous studies largely considered data from the period before the shocking collapse of the Lehman Brothers in 2008, the present study focuses on the more recent period from March 2009 to March 2013. As the main point of difference from previous research, this study examines the effects by gender diversity on managerial efficiency by examining the effects on both profitability and risk. If either increase of profitability or decrease of risk occurs, it is interpreted that managerial efficiency is improved. Thus, both a decrease of risk under constant profitability and an increase of profitability under constant risk mean the improvement of managerial efficiency. Compared with previous studies, facts on managerial efficiency using recent data in Japan are unique and effective for the management of Japanese companies.

\section{Data and method of analyses}

Analyses were conducted using corporate financial performance (CFP) as the dependent variable and corporate social performance (CSP) as the explanatory variable. In this study, the excess stock return, ROA, and stock price volatility are selected as CFP and five female factors are selected as CSP. Table 1 depicts the five female factors. Effects by CSPi1 and CSP $i 5$ have been verified by many previous works. Here, executives refers to members of boards of directors, statutory auditors, executive directors, and executive officers. The other three factors measure companies' efforts to utilize female workforce and improve the working environment. These factors have received little attention in previous studies; therefore, new and unique facts are expected to be generated. Market capitalization and the ratio of interest-bearing liabilities are used as control variables for scale effects and financial risk caused by differences in capital structure, respectively. Average annual salary is assumed to measure the companies' working environment. Fiscal year dummy variables are also utilized as control variables. As dependent variables, excess stock return is the annual stock return for one fiscal year after female factors are obtained. ROA, calculated by dividing earnings before interest and taxes(EBIT) by average total assets, corresponds to the same period. ROA and the excess stock return have been frequently used in many previous studies to measure companies' present and future performances, respectively. Stock price volatility refers to the standard deviation of the stock's monthly return for the same period as that of the excess stock return. This has received little attention in previous studies; therefore, new and unique facts are expected to be generated.

Table 1 CSP: Female Factors (in the i-th firm)

\begin{tabular}{|c|l|}
\hline Female Factors & \multicolumn{1}{|c|}{ Description } \\
\hline CSPi1 & $\begin{array}{l}\text { Percentage of female executives relative to } \\
\text { total executives }\end{array}$ \\
\hline CSPi2 & $\begin{array}{l}\text { Percentage of employees taking maternity } \\
\text { leave relative to all employees in each fiscal } \\
\text { year }\end{array}$ \\
\hline CSPi3 & $\begin{array}{l}\text { Percentage of female employees relative to } \\
\text { all employees in each fiscal year }\end{array}$ \\
\hline CSPi4 & $\begin{array}{l}\text { Average duration of service of female } \\
\text { employees for each fiscal year }\end{array}$ \\
\hline CSPi5 & $\begin{array}{l}\text { Percentage of women in managerial } \\
\text { positions above department manager level } \\
\text { relative to all managers }\end{array}$ \\
\hline
\end{tabular}

The source of female factors is [8]. The selected samples were obtained from 3,015 firms listed on the Tokyo Stock Exchange, and those with no data are

International Journal of Japan Association for Management Systems 
excluded. The target horizons are the fiscal years ending March 31 for each year from 2009 to 2013. The software used in this study is SPSS ver. 23.0.

The impact of the female factors on the CFP are analyzed using the model below for each CFP as a dependent variable.

$$
\begin{aligned}
\text { CFPit }=\boldsymbol{\alpha} \boldsymbol{j}+ & \sum_{j=1}^{5} \boldsymbol{\beta}_{j} \text { CSPijt }+\boldsymbol{\beta}_{M K} \log M K i t \\
& +\boldsymbol{\beta}_{I L} I L i t+\beta_{A S} \log A S i t+\sum_{\mathrm{t}} \beta_{Y D t} Y D t
\end{aligned}
$$

$\ldots(1)$

CFPit $=$ excess stock return or stock price volatility of stock i price for the $t$-th year

CSPijt $=\mathrm{j}$-th female factor of the $\mathrm{i}$-th firm in the $\mathrm{t}$-th year

MKit $=$ market capitalization of the i-th firm in the $\mathrm{t}$ th year

ILit $=$ ratio of interest-bearing liabilities of the i-th firm in the $\mathrm{t}$-th year

ASit $=$ average annual salary of the i-th firm in the tth year

$Y D t=\mathrm{t}$-th year dummy

Figure 1: Model and causal relationship

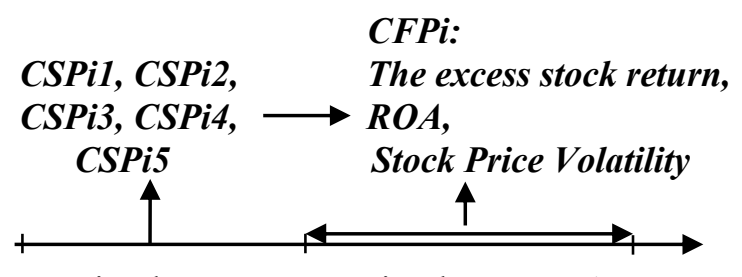

Fiscal Year $\mathrm{t} \quad$ Fiscal Year $\mathrm{t}+1$

In addition to conducting analyses for all industries, we analyzed each industry with a large number of samples.

\section{Results and Discussion}

\subsection{Relationship between female factors and excess stock return}

Table 2: Female Factors and Excess Stock Return

\begin{tabular}{|c|c|c|c|c|c|}
\hline $\boldsymbol{\beta}_{2}$ & -0.860 & -0.211 & -1.661 & -0.824 & \\
\hline$\beta_{3}$ & 0.001 & 0.284 & -0.003 & -1.560 & \\
\hline$\beta_{4}$ & 0.003 & 0.581 & -0.004 & -0.625 & \\
\hline \multirow[t]{3}{*}{$\beta_{5}$} & -0.014 & -1.001 & 0.006 & 1.053 & \\
\hline & \multicolumn{2}{|c|}{$\begin{array}{l}\text { Electric Machinery }(\mathrm{n}= \\
311)\end{array}$} & \multicolumn{3}{|c|}{$\begin{array}{c}\text { Financial Business }(\mathrm{n}= \\
164)\end{array}$} \\
\hline & & t-stats & & t-stats & \\
\hline$\beta_{1}$ & -0.013 & -0.680 & -0.003 & -0.291 & \\
\hline $\boldsymbol{\beta}_{2}$ & 0.000 & 0.000 & -0.103 & -0.553 & \\
\hline$\beta_{3}$ & -0.004 & -1.402 & -0.005 & -1.457 & \\
\hline $\boldsymbol{\beta}_{4}$ & -0.004 & -0.604 & -0.003 & -0.434 & \\
\hline \multirow[t]{3}{*}{$\beta_{5}$} & -0.019 & -0.911 & 0.008 & 0.951 & \\
\hline & \multicolumn{2}{|c|}{$\begin{array}{c}\text { Transportation Equipment } \\
(\mathrm{n}=151)\end{array}$} & \multicolumn{3}{|c|}{ Service $(n=104)$} \\
\hline & & t-stats & & t-stats & \\
\hline $\boldsymbol{\beta}_{1}$ & -0.007 & -0.460 & 0.000 & 0.070 & \\
\hline $\boldsymbol{\beta}_{2}$ & -8.908 & -0.601 & 5.170 & 2.200 & $* *$ \\
\hline $\boldsymbol{\beta}_{3}$ & -0.006 & -0.634 & 0.002 & 1.130 & \\
\hline$\beta_{4}$ & 0.011 & 0.678 & -0.003 & -0.350 & \\
\hline $\boldsymbol{\beta}_{5}$ & -0.022 & -0.347 & -0.010 & -2.402 & * \\
\hline
\end{tabular}

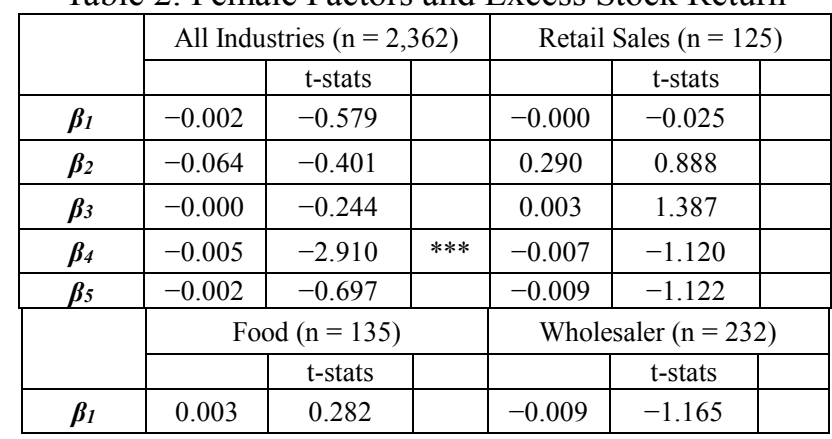

$*, * *$, and $* * *$ indicate significance at the $10 \%, 5 \%$, and $1 \%$ levels, respectively.

Table 2 quantifies the impact of female factors on excess stock return, which is an estimate of a company's future value; for all industries, longer duration of service for women had a negatively significant effect. Furthermore, in the service sector, the higher the percentage of female managers, the larger the negative impact on excess stock return. Conversely, in the service sector, the higher the percentage of women taking maternity leave, the more the female factor had a positively significant effect on excess stock return.

Although significant effects were identified in the case of several industries, it cannot be inferred that the female factor is considered to determine corporate stock prices.

\subsection{Relationship between the female factors and ROA}

\begin{tabular}{|c|c|c|c|c|c|c|}
\hline & \multicolumn{3}{|c|}{ All Industries $(n=2,362)$} & \multicolumn{3}{|c|}{ Retail Sales $(\mathrm{n}=125)$} \\
\hline & & t-stats & & & t-stats & \\
\hline$\beta_{1}$ & 1.700 & 0.535 & & -0.130 & -1.780 & $*$ \\
\hline$\beta_{2}$ & 19.784 & 0.127 & & -0.541 & -1.643 & \\
\hline$\beta_{3}$ & 0.160 & 0.229 & & -0.004 & -0.202 & \\
\hline $\boldsymbol{\beta}_{4}$ & 0.554 & 0.300 & & -0.227 & -3.577 & $* * *$ \\
\hline \multirow[t]{3}{*}{$\beta_{5}$} & -3.464 & -1.184 & & 0.141 & 1.602 & \\
\hline & \multicolumn{3}{|c|}{ Food $(n=135)$} & \multicolumn{3}{|c|}{ Wholesaler $(n=232)$} \\
\hline & & t-stats & & & t-stats & \\
\hline$\beta_{1}$ & 0.273 & 2.808 & $* * *$ & -0.005 & -0.064 & \\
\hline
\end{tabular}

Table 3: Female Factors and ROA

Vol. 7 No.1 (2015) 


\begin{tabular}{|c|c|c|c|c|c|c|}
\hline $\boldsymbol{\beta}_{2}$ & -0.111 & -0.002 & & -2.158 & -0.100 & \\
\hline$\beta_{3}$ & -0.038 & -1.375 & & -0.030 & -0.995 & \\
\hline $\boldsymbol{\beta}_{4}$ & -0.110 & -1.670 & $*$ & -0.160 & -2.585 & $* *$ \\
\hline$\beta_{5}$ & -0.039 & -0.269 & & -0.015 & -0.290 & \\
\hline & \multicolumn{3}{|c|}{$\begin{array}{l}\text { Electric Machinery }(\mathrm{n}= \\
311)\end{array}$} & \multicolumn{3}{|c|}{$\begin{array}{c}\text { Financial Business }(\mathrm{n}= \\
164)\end{array}$} \\
\hline & & t-stats & & & t-stats & \\
\hline$\beta_{1}$ & -0.154 & -0.502 & & 49.771 & 0.842 & \\
\hline$\beta_{2}$ & -11.221 & -0.601 & & 272.553 & 0.280 & \\
\hline$\beta_{3}$ & 0.100 & 1.890 & $*$ & 11.662 & 0.863 & \\
\hline $\boldsymbol{\beta}_{4}$ & -0.093 & -1.211 & & 34.733 & 0.799 & \\
\hline \multirow[t]{3}{*}{$\beta_{5}$} & 0.280 & 0.802 & & -39.023 & -0.900 & \\
\hline & \multicolumn{3}{|c|}{$\begin{array}{l}\text { Transportation Equipment } \\
\qquad(\mathrm{n}=151)\end{array}$} & \multicolumn{3}{|c|}{ Service $(n=104)$} \\
\hline & & t-stats & & & t-stats & \\
\hline$\beta_{1}$ & -0.160 & -1.321 & & 0.103 & 0.555 & \\
\hline$\beta_{2}$ & -140.700 & -1.300 & & 65.441 & 0.799 & \\
\hline$\beta_{3}$ & 0.071 & 0.900 & & 0.081 & 1.405 & \\
\hline $\boldsymbol{\beta}_{4}$ & 0.030 & 0.267 & & 0.988 & 2.911 & $* * *$ \\
\hline$\beta_{5}$ & -0.009 & -0.020 & & -0.123 & -0.922 & \\
\hline
\end{tabular}

$*, * *$, and $* * *$ indicate significance at the $10 \%, 5 \%$, and $1 \%$ levels, respectively.

Table 3 quantifies the impact of female factors on ROA. Although a significant result was not obtained with respect to the aggregate for all industries, significance was observed in some industries. This implies the existence of industrial effects, i.e., there are different effects in each industry. In the food industry, a high percentage of women executives led to a significant positive impact on ROA. In the electrical machinery industry, a high percentage of women employees led to a significant positive impact on ROA, and in the service sector, a longer duration of service by female employees had a significant positive impact on ROA.

However, in retail sales, a longer duration of service by female employees and a higher percentage of female executives had a significant negative impact on ROA. In the food industry and wholesale business, a longer duration of service by female employees had a significant negative impact on ROA. On the basis of these facts, it can be hypothesized that such industries employ a large number young women, and their duration of service increases in steady companies with low business risk and low ROA.

In the food industry, it is estimated that career advancement for women leads to higher ROA, whereas employment longevity without career advancement for women leads to lower ROA. In this industry, since women's preferences are believed to have a major impact on corporate performance; if more women obtain managerial positions and their opinions are influential, then the female factors will contribute to improving corporate performance.

In the electrical machinery industry and the service sector, it is estimated that the presence of women employees in a company generates positive effects on corporate earnings. Especially in the service sector, longer service of females remarkably enhances ROA. This observation can be explained by dependence of the service sector on female workforce.

\subsection{Relationship between female factors and stock price volatility}

Table 4: Female Factor and Stock Price Volatility

\begin{tabular}{|c|c|c|c|c|c|c|}
\hline & \multicolumn{3}{|c|}{ All Industries $(\mathrm{n}=2,362)$} & \multicolumn{3}{|c|}{ Retail Sales $(\mathrm{n}=125)$} \\
\hline & & t-stats & & & t-stats & \\
\hline $\boldsymbol{\beta}_{1}$ & -0.004 & -2.152 & $* *$ & 0.006 & 1.548 & \\
\hline $\boldsymbol{\beta}_{2}$ & 0.047 & 0.501 & & 0.396 & 1.898 & $*$ \\
\hline$\beta_{3}$ & -0.001 & -3.521 & $* * *$ & 0.004 & 3.299 & $* * *$ \\
\hline$\beta_{4}$ & -0.003 & -3.498 & $* * *$ & -0.007 & -1.887 & $*$ \\
\hline \multirow[t]{3}{*}{$\beta_{5}$} & 0.003 & 2.098 & $* *$ & -0.006 & -1.100 & \\
\hline & \multicolumn{3}{|c|}{ Food $(n=135)$} & \multicolumn{3}{|c|}{ Wholesaler $(\mathrm{n}=232)$} \\
\hline & & t-stats & & & t-stats & \\
\hline$\beta_{1}$ & -0.005 & -1.115 & & 0.003 & 0.612 & \\
\hline $\boldsymbol{\beta}_{2}$ & 0.344 & 0.171 & & 1.8101 & 1.505 & \\
\hline$\beta_{3}$ & -0.004 & -2.998 & $* * *$ & 0.000 & 0.267 & \\
\hline$\beta_{4}$ & 0.003 & 1.109 & & -0.002 & -0.498 & \\
\hline \multirow[t]{3}{*}{$\beta_{5}$} & 0.030 & 4.324 & $* * *$ & -0.003 & -0.898 & \\
\hline & \multicolumn{3}{|c|}{$\begin{array}{l}\text { Electric Machinery }(\mathrm{n}= \\
311)\end{array}$} & \multicolumn{3}{|c|}{$\begin{array}{l}\text { Financial Business }(\mathrm{n}= \\
164)\end{array}$} \\
\hline & & t-stats & & & t-stats & \\
\hline$\beta_{1}$ & -0.031 & -3.673 & $* * *$ & -0.010 & -1.400 & \\
\hline$\beta_{2}$ & 1.098 & 2.320 & $* *$ & 0.067 & 0.554 & \\
\hline$\beta_{3}$ & -0.004 & -2.586 & $* * *$ & 0.001 & 0.289 & \\
\hline$\beta_{4}$ & -0.002 & -0.589 & & -0.024 & -4.187 & $* * *$ \\
\hline \multirow[t]{3}{*}{$\beta_{5}$} & -0.004 & -0.400 & & 0.018 & 3.011 & $* * *$ \\
\hline & \multicolumn{3}{|c|}{$\begin{array}{l}\text { Transportation Equipment } \\
(\mathrm{n}=151)\end{array}$} & \multicolumn{3}{|c|}{ Service $(n=104)$} \\
\hline & & t-stats & & & t-stats & \\
\hline$\beta_{1}$ & -0.017 & -2.673 & $* * *$ & 0.000 & 0.003 & \\
\hline $\boldsymbol{\beta}_{2}$ & -16.763 & -2.309 & $* *$ & 0.798 & 0.419 & \\
\hline$\beta_{3}$ & 0.008 & 1.932 & $* *$ & 0.001 & 1.188 & \\
\hline$\beta_{4}$ & 0.014 & 1.750 & $*$ & -0.009 & -1.100 & \\
\hline$\beta_{5}$ & -0.003 & -0.133 & & -0.005 & -1.499 & \\
\hline
\end{tabular}

$*, * *$, and $* * *$ indicate significance at the $10 \%, 5 \%$, and $1 \%$ levels, respectively.

Various evaluation results were obtained for the impact of female factors on stock price volatility, as presented in Table 4. Based on the overall tendency, employing many women for a long time has the effect of decreasing the risk that the companies bear. However, on promotion, gender diversity among boards of 
directors decreases the risk rather than promoting a large amount of women.

In the retail and the electrical machinery industries, a higher percentage of women taking maternity leave increased stock price volatility; however, the results are opposite in the transportation equipment industry. A higher percentage of female employees in the retail and transportation equipment industries increased stock price volatility. However, for the food electrical machinery industries, the results were opposite. Women's duration of service increased stock price volatility, whereas for the retail and the financial industry, the results were the reverse. The increased percentage of women executives in the aggregate, electrical machinery, and transportation industries decreased stock price volatility. The higher percentage of female managers in the food and financial industries increased stock price volatility.

\section{Conclusions}

As a result of its declining birthrate and aging population, Japan's labor force is expected to continue shrinking. Our study investigated whether greater utilization of the female workforce can mitigate or overcome the shrinkage in the labor force. It is empirically examined whether the female factor has an impact on corporate earnings and corporate risk.

Previous studies have confirmed that the female factor has both positive and negative impacts on corporate profitability. This study examines the effects on managerial efficiency by examining the effects on both profitability and risk. The results are summarized in Table 5.

Table 5: Effects on Managerial Efficiency

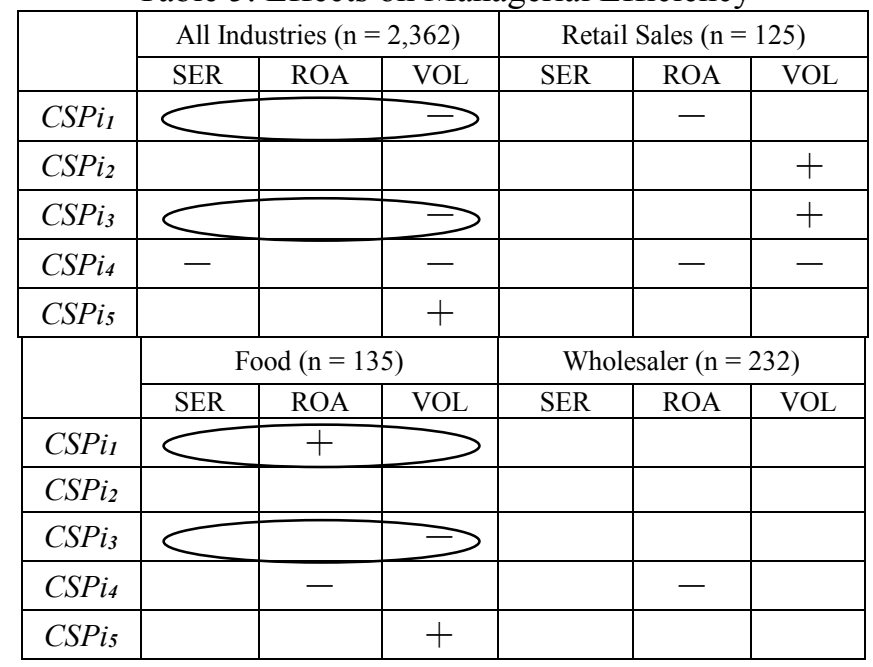

\begin{tabular}{|c|c|c|c|c|c|c|}
\hline & \multicolumn{3}{|c|}{$\begin{array}{l}\text { Electric Machinery }(\mathrm{n}= \\
311)\end{array}$} & \multicolumn{3}{|c|}{ Financial Business $(n=164)$} \\
\hline & SER & ROA & VOL & SER & ROA & VOL \\
\hline $\mathrm{CSP}_{1}$ & 5 & & $\Rightarrow$ & & & \\
\hline $\mathrm{CSPi}_{2}$ & & & + & & & \\
\hline $\mathrm{CSPi}_{3}$ & $<$ & & $\Rightarrow$ & & & \\
\hline $\mathrm{CSP}_{4}$ & & & & $<$ & & $\Rightarrow$ \\
\hline \multirow[t]{3}{*}{$\mathrm{CSPi}_{5}$} & & & & & & + \\
\hline & \multicolumn{3}{|c|}{$\begin{array}{c}\text { Transportation Equipment } \\
(\mathrm{n}=151)\end{array}$} & \multicolumn{3}{|c|}{ Service $(n=104)$} \\
\hline & SER & ROA & VOL & SER & ROA & $\mathrm{VOL}$ \\
\hline $\mathrm{CSP}_{i_{1}}$ & $<$ & & $\Rightarrow$ & & & \\
\hline $\mathrm{CSPi}_{2}$ & $<$ & & $\Rightarrow$ & $\leftarrow$ & & 3 \\
\hline $\mathrm{CSPi}_{3}$ & & & + & & & \\
\hline $\mathrm{CSP}_{4}$ & & & + & $<$ & + & 3 \\
\hline $\mathrm{CSP}_{5}$ & & & & - & & \\
\hline
\end{tabular}

ESR: excess stock return

VOL: stock price volatility

Results enclosed within the circles indicate the improvement of managerial efficiency. As an overall trend, gender diversity among executives and new employees improves managerial efficiency. Similar are confirmed in the food and electric machinery industries. In addition, industrial effects are confirmed; for example, the increase in duration of service of women improves managerial efficiency in the financial and service sectors, which greatly depend on female labor. Moreover, the percentage of employees taking maternity leave improves managerial efficiency in the transportation equipment and service sectors. Compared with previous studies, these recent data are unique and informative for the effective management of Japanese companies.

This study found several recent facts concerning the gender diversity effects on Japanese corporate performance by examining the effects on managerial efficiency and is positioned as one of the trials to derive managerial implication and political implication. As suggestive researches concerning future tasks of this study, [9] examined the gender diversity effects on the productivity and competitiveness measured by GDP per unit working hour or gross sales per employee's unit working hour. As results, higher female percentage of the management or highlyeducated female employee raises the productivity and competitiveness, and Japanese companies are pointed out to fail in utilization of human resources of a highlyeducated female employees. [10] confirmed that corporates' work life balance policy raises salary of female employees graduating from university or

Vol. 7 No.1 (2015) 
college. As future tasks, analyses in this study can be more precise by adopting other variables measuring gender diversity effects on corporate performance more precisely and adopting control variables measuring the ability of the female employees.

\section{References}

[1] N. L. Erhardt, J.D.Werbel and C.B.Shrader: Board of Director Diversity and Firm Financial Performance. Corporate governance, 11(2) (2003), 102-111.

[2] A.Carter, B.J.Simkins and W.J.Simpson: Corporate Governance, Board Diversity, and Firm Value.

Financial Review, 38 (2003), 33-53.

[3] A.K.Farrell and P.L.Hersch: Addition to Corporate Boards: The Effect of Gender. Journal of Corporate Finance, 11 (2005), 85-106

[4] R.B.Adams, and D.Ferreira: A Theory of Friendly

Boards. The Journal of Finance, 62(1) (2007), 215-250. [5] S.E.Page: The Difference: How the Power of Diversity Creates Better Groups, Firms, Schools and Societies (2007), Princeton University Press.

[6] S. Tsujimoto,: Women Directors and Firm Performance. Annals of Society for the Economic Studies of Securities, 48 (2013), 73-91

[7] K.R.Ahern, and A.K.Ditmar: The Changing of the Boards: The Impact on Firm Valuation of Mandated Female Board Representation. The Quarterly Journal of Economics, 127(1) (2012), 137-197.

[8] Toyo Keizai Directory of CSR Corporations (Data Disc): Employment and Utilization of Human Resources 2009-2013, Toyo Keizai Inc.

[9] K.Yamaguchi: Roudouseisansei to danjyokyoudousankaku -naze nihonkigyou wa damenanoka, jyoseijinzaikatsuyou wo yuukounisuruitameni kigyou wa nani wo nasubekika, kuniwa naniwonasubekika -. RIETI Discussion Paper Series 11-J-069 (2011).

[10] K.Yamaguchi: Extensions of Rubin's Causal Model for a Latent-Class Treatment Variable: An analysis of the effects of employers' work-life balance policies on women's income attainment in Japan. RIETI Discussion Paper Series 15-E-090 (2015). 